\title{
Remote education of students with disabilities in inclusive forms of education in Poland during the COVID-19 pandemic
}

\author{
Iwona Chrzanowska ${ }^{1}$ \\ ${ }^{1}$ Faculty of Educational Studies, Adam Mickiewicz University, Poland
}

\begin{abstract}
HOW TO CITE:
Chrzanowska, I. (2021).

Remote education of students

with disabilities in inclusive forms

of education in Poland during

the COVID-19 pandemic.

International Journal

of Special Education, 36(2), 44-52

CORRESPONDING AUTHOR:

Iwona Chrzanowska;

chrzanowska.iwona1@gmail.com

DOI:
\end{abstract}

https://doi.org/10.52291/ijse.2021.36.17

COPYRIGHT STATEMENT:

Copyright: (C) 2021 Authors.

Open access publication under the terms and conditions

of the Creative Commons

Attribution (CC BY)

license (http://creativecommons.

org/licenses/by/4.0/).

\begin{abstract}
:
Remote education during the COVID-19 pandemic has become a challenge for educational practice worldwide. Students with disabilities found themselves in an unusual situation in inclusive forms of education. This article presents the results of qualitative research conducted within a group of 34 teachers of older primary classes (IV-VIII), who, during the pandemic, had among the children they were teaching students with disabilities. Study aim was to evaluate how is online education of these students is conducted. As a result of the research, three descriptive categories of problems with remote education of students with disabilities emerged: participation in (remote) classes of the disabled students; development/regress of competencies of students with a disability due to online education; educational perspectives - inclusive education of students with a disability after the pandemic ends. The results of the research can be a base for reflection about the necessary actions supporting students with disabilities and their teachers in the perspective of returning to school and the execution of the inclusive education idea in Poland.
\end{abstract}

Keywords: remote teaching; students with disabilities; inclusive form of education. 


\section{INTRODUCTION}

As presented by Sakellariou, Serrata, Malfitano, and Rotarou (2020) in the initial stage of the COVID-19 pandemic, the virus was often called 'a grand eliminator'. It referred to the belief that in the face of such a crisis as the pandemic everyone is equally endangered with the possibility of being sick. Unfortunately, despite the fact that the virus does not choose, it does sharpen distinctively the inequalities. This refers to protection against the risk of infection, medical treatment accessibility, access to education, keeping the job, et cetera. Due to this, it unproportionally affects the part of the population that for some reason is in a worse situation. (Douglas et al., 2020).

Disabled people are often perceived as especially endangered by the pandemic risk, its effects, or socio-economical repercussions (Sakellariou et al., 2020). There is a justified fear that disabled people can be inadequately protected against the risk of further impoverishment as a result of the economical consequences of COVID-19.

A special group in this context is disabled children, who according to UNICEF (Child disability and COVID-19) belong to a group most affected by the process of marginalization in connection to the pandemic situation and reformatting of helping and supporting actions. There are also common fears present regarding the effect of social isolation or social distancing on a child's well-being, including increased anxiety, depression, stress, and fear of increasing or returning to previous existing problems connected with mental health (Holmes, et al. 2020). Disabled children can experience the negative results of isolation in particular. This can be connected with increasing problems linked with disorders as an effect of limited access to therapy and offline rehabilitation, as well as problems connected with family relations, parental helplessness in terms of managing the child's behaviour.

A separate problem is the education of disabled people. According to UNESCO data (2020), the education of disabled students in remote forms has more obstacles than in the case of non-disabled students. The crisis resulting from COVID-19 shows that disabled people receive less help and support than earlier, and non-disabled people. There is also less attention paid to issues connected with disabled people's education in times of the pandemic than to non-disabled people (UNICEF, 2020). Thinking of education in terms of inclusion
(Savolainen et al., 2012) thus perceive it as one of the basic human rights, attention should still be paid to all possible obstacles in fulfilling these rights (Mitchell, 2005; Walton, 2015). It seems that COVID-19 especially highlights some of them. It refers to, for example, differentiated chances for effective education connected with a type or level of disability that before the pandemic had been perceived as one of the main obstacles (Avramidis et al., 2000; Forlin, 2001; Avramidis \& Norwich, 2002; Evans \& Lunt, 2002; Thomas \& Loxley, 2007; Hansen, 2012; Gallagher \& Bennett, 2015). Physical, sensory, or mild intellectual disabilities were perceived almost three decades ago in categories of higher chances in terms of joint education than, for example, serious behavioural disorders (Scruggs \& Mastropieri, 1996; Soodak et al., 1998).

The second category of problems that seems to be highlighted by the COVID-19 situation is the teacher's competencies to work with the pupil and their support in this area (Mitchell \& Hedge, 2007; Westwood, 2013). The pandemic situation has drastically changed the conditions of education in the whole world. The necessity to move to remote education has shown a new area of weakness in teachers' competencies. It turns out that $9 \%$ of the teachers do not feel comfortable using technology tools needed in remote teaching. IT competencies, including usage of remote education tools, are connected with the age of the teachers. Among a group of teachers with a working length of 20-29 years, $13 \%$ of teachers declared such problems; in a group above 30 years it is already $22 \%$ in comparison to $6 \%$ in a group of fewer than 10 years; and 7\% in a group of $10-19$ years (Kraft $\&$ Simon, 2020).

A reported problem is also the presence of students during classes. The teachers show that on average $60 \%$ of students regularly attend remote lessons. These numbers are visibly lower in societies affected by any of the exclusion aspects. In the case of poverty, it is only $50 \%$ of students, with a level of $75 \%$ when the problem is non-existent. The research shows that the support for teachers in these environments is also smaller (Kraft \& Simon, 2020,7); and this situation was also present before the pandemic (Johson et al., 2012).

When it comes to technical possibilities of the students (access to IT tools) 75\% of the teachers state that the students have necessary tools, but they are differentiated in terms of economical possibilities of the family, 
student's environment. Only $64 \%$ in impoverished environments have such possibilities in comparison to $87 \%$ in environments of low levels of poverty (Kraft \& Simon, 2020, p. 8).

In Poland, similarly to other countries, the percentage of families with a disabled child affected by financial difficulties is bigger than in the general population. The average monthly income per person is $16.6 \%$ lower than the national average. The statistics presented by the Central Statistical Office in Poland show that the financial situation of families with a disabled person is relatively worse than in the general population. The expenses of these families per person are lower even by several per cent (14.9\%) (Janoś-Kresło \& Słaby, 2016).

During the pandemic, the education of disabled people in Poland was carried out in different ways. Special schools (schools where only disabled children are taught) can carry out on-site education. The decision about any other forms is made individually each time by the Head of the School. The situation of students who before the pandemic had had their education in one of the inclusive forms: in an integration school or general school, is different. In this case, the students, just like their peers without any disabilities, were moved to remote or hybrid learning. Such solutions are mostly carried out in the majority of the world. Their intensity, dominance of one of the forms is connected with the dynamically changing situation and the number of ill people.

The main research problem was set in a very general way according to the methodology of interpretative research and: How is the remote education of students with disabilities conducted in inclusive forms of education?

\section{METHODS}

\section{Study participants}

The research was done in an interpretative paradigm (Guba \& Lincoln 1982), among teachers from integration and general schools. In Polish educational solutions, an 'integrational class' is a special, legally sanctioned way of education, where up to 5 students are children with disabilities and the remaining 15 are children without any developmental disorders falling into special education needs. Additionally, these classes have two teachers (a teacher and a special educationalist). General schools (mainstream schools) are schools that both disabled and non-disabled children can attend. There are no detailed regulations as to the number of students with or without disabilities, and there is no double teacher staffing.

The research focused on teachers working in inclusive forms of education (Surveys were carried out using the Microsoft Teams platform, a tool known to teachers as it has been used since the beginning of the pandemic for remote education.

The criteria to include in the research group were: work in older classes of integration and/or general primary school attended by students with disabilities; remote education execution.

The exclusion criterion was the teacher's inexperience in working with a disabled child at a mainstream school (in the school where the teacher works, the student was never a disabled child).

The invitation to the meeting was accepted by 34 teachers of older primary classes (IV-VIII).

Both teachers of humanities and science participated in the research. The length of work was different. There were 9 teachers (about 26\%) working up to 10 years, 14 (about 41\%) working from 11 to 20 years, and 11 (about $23 \%)$ working more than 20 years. In the research group, the majority were women (about 70\%, 24 people). The responses were coded according to the key: W/M - woman, man (the number assigned to the research after a dash: in case of women from 1 to 24 ; in case of men from 1 to 10 ); 1/2/3: 1 - work experience group up to 10 years; 2 - work experience group 11-23 years; 3 - work experience group above 20 years; $\mathrm{H} / \mathrm{S}$ - subject taught: humanities/science.

\section{RESULTS}

The performed research allowed the distinguishing of 3 main (the most commonly appearing answers) specific issues regarding (1) participation of students with disabilities in remote lessons; (2) development/regress of competencies of students with disabilities as an effect of remote education; (3) educational perspectives - education of students with disabilities, special educational needs after the pandemic.

First thread - participation of the students with disabilities in remote classes

Teachers agree that remote education is a big challenge for students with disabilities. Bigger than for stu- 
dents with no developmental disorders. Students with disabilities, special educational needs:

- adapt longer to new situations than their non-disabled peers;

- have problems with attendance more often;

- cope worse with the technical aspect of remote learning;

- need more parental control and support;

- lose motivation to work quicker;

- gain less as a result of remote learning than onsite learning.

Here are some examples of teachers' responses:

"(...) they are more lost than their friends, react slower to instructions, they cannot find, for example, the file with tasks" (W - 7/2/H).

"Initially they managed technically poorly with remote learning. With time it was better but still worse than in the case of their non-disabled friends. They use remote learning less" $(\mathrm{M}-3 / 1 / \mathrm{S})$.

"It depends on the student, the type of disability. The biggest is the problem with hyperactive students. They are not able to sit in front of the computer for all lessons, they leave, don't come back when I ask them. I could react in the class, but here there are no possibilities, it is difficult" (W-8/2/S).

Teachers point out possible greater negative results of remote learning in a social aspect rather than a didactic one. Relationship with friends is one of the key factors of inclusive education in the case of students with disabilities. They allow obtaining competencies that in the future allow them to function better in an open society.

"Remote education is a bigger challenge for students with disabilities. I think, didactically it is not that bad, they do their homework if the teacher runs the class well. They are also the same active students, but socially there is and will be a problem" $(M-2 / 2 / S)$. (...) seclusion from their friends will result at best in slowing the development of social competencies of disabled students" (W $-24 / 3 / \mathrm{H})$.

Another problem noticed by a big group of teachers is the phenomenon of "disappearing" students. Teachers report that with some students they have no contact, or it is limited. This problem was reported by about $50 \%$ of the research group. It turned out that a larger group of teachers from big cities rather than small towns point to this as a major issue (about $51 \%$ to about $30 \%$ ).

"There is a problem with the attendance in class, they [students with disabilities] are late more often, or they do not participate in lessons at all. They need greater parental control" (W-12/3/S).

"They get discouraged quicker if something does not work out. They seem to be present, but they do not participate" (W - 15/2/H).

"There are some students I have no contact with, after the first meeting they did not participate in the following. Interventions, text messages, e-mails did not help" $(\mathrm{M}-8 / 3 / \mathrm{S})$.

"I have students with SEN that do not attend classes. Parents say they have no equipment. The school is trying to help, but the needs are greater than the possibilities" (W-21/3/S).

"I work in a village and a town school. The attendance is worse in the city. I think the problem is with parents' remote work. More people work in the city than in the countryside" $(\mathrm{M}-5 / 1 / \mathrm{H})$.

Access to IT tools or old, often breaking equipment, as well as IT competencies are the most common problem among students with disabilities. It is connected with, as pointed out as well by the teachers participating in the research, a worse economic situation of the families. It is confirmed by research carried out around the world for a long time (Kuhlthau \& Perrin, 2001, Kuhlthau et al., 2005, Parish \& Cloud, 2006, Purdam et al., 2008, Skivington, 2011, Pinilla-Roncancio, 2015,). Teachers point out that the more difficult the economic situation of families with a disabled child is a serious problem in their remote education.

"Students with disabilities have problems with connecting more often. There is not enough equipment at home for remote work, especially when parents and siblings also work remotely. Data transfer is a problem. It was quite often that during the lesson the connection was lost and the work could not be continued" (W - 17/1/S).

\section{Second thread - development/regress of competencies.}

There is a complex picture emerging from teachers' answers regarding the development of competencies as a result of remote learning. The first plan in terms of organization of education shows low IT competencies of the students, especially when they do not have support in the IT competencies of their parents.

"Students with disabilities have lower competencies in computer skills and this, connected with old equipment, is a serious problem" $(\mathrm{M}-7 / 2 / \mathrm{S})$.

"IT competencies are the problem of many students, not only those with disabilities. We say our children are the digital generation, but this is not true. Their com- 
petencies are selective, they are connected with using their smartphones and social media. Work on Teams or any other platform turned out to be problematic" (M $9 / 1 / S)$.

"IT competencies among children are low, selective, it is worse than even their parents, this is more common in case of children with lower education, or from areas where there is no well-functioning internet infrastructure" (W - 13/2/S).

"The problems are also inequalities in digital competencies of the parents. Unfortunately, it is so that usually if the parents do not have them, then the children are also not good with them" (W-16/3/H).

Remote education, however, is also a chance to gain new skills or perfecting the existing ones.

"Teachers are no longer the only source of information, and it is very good. Finally, Internet sources will be used. Students are eager to search for information when they finally learn how to do it, and at the same time, they also learn to critically look at the content found on the Internet. It will help them greatly in the future" $(\mathrm{M}-4 / 3 / \mathrm{H})$.

"The Internet is no longer only a tool for entertainment. Many students were authentically surprised by how many interesting things they can learn" (W-3/1/H).

"Remote lessons can teach students to be responsible for themselves and their work" (W-5/1H).

"I have noticed an interesting phenomenon, the work of my students who up till now was not particularly good at mathematics has visibly improved (...) unfortunately, it turned out that it was the parents who did the work" (W-18/1/S).

Fears connected with the social functioning of students with disabilities are present in every response of every teacher.

"Remote education is a completely new experience. Students in the majority have their cameras and microphones off during the lessons. You do not know if the student is by the computer, you do not know who you are talking to, you do not know what the student is doing, you cannot react to non-verbal communication. In normal conditions, I knew which student understood the instructions, which one needed repeating or having it paraphrased. It is especially connected with students who have some difficulties in learning. I cannot ask every student and make sure they understood; if they know what to do because this disorganizes the work. This is very difficult" (W-23/2/H).
"Problems with concentration are getting bigger [about a student with ADHD], following the lesson, it is enlarged by the necessity to operate different applications" (W-1/3/H).

"It seems as she is present only physically [female student with a minor intellectual disability], she avoids answering questions, for example, disconnects" (W-2/2/H).

"Constant parental control is also not a good solution. It's as if the child stops self-control, responsibility development" (M-10/2/S).

"Continual presence of the parent during the lesson, in the case of a child with a disability, has many disadvantages. Constant supervision is zero responsibility for the child, they have no natural interactions with peers" (W-10/3/H).

"Children with disabilities show symptoms of helplessness quicker. It needs a lot of control in order not to do things for the child. Parental assistance for the child during the lesson takes over some of the tasks. This is not a good solution because it is not the child's work, but the parent's. The child gets used to the help quickly and expects it more often" (W-6/3/S).

"Many children are already in a bad mental condition resulting from the lack of contact with their peers" (W-9/2/H).

"During the pandemic, there is no continuity of rehabilitation and therapy, it shows in the students' behavior. Parents are not always able to cope with it. It is a fatal situation, regress is visible, for example, in concentration and attention" (W-20/2/H).

\section{Third thread-perspectives of inclusive education after the pandemic ceases}

Teachers are afraid to come back to schools because they are aware there might be more, new educational problems:

"There will be problems with discipline. Anonymity of remote education is bigger than in an onsite one. I do not see all, I do not hear all especially when the student wants it" (W-19/3/H).

The research group agrees that remote education will contribute to a significant lack in terms of students' knowledge and skills. After returning to school, according to them, it will be necessary to eliminate the deficiencies. Many teachers point out the need of repeating the curriculum.

"There is no doubt, the curriculum will have to be repeated after returning to school. In chemistry or physics, there is practically no possibility to conduct experiments. 
It is as if we moved back in didactics to the feeding method. Students at most can observe the experiments I conducted. In normal situations we would do them ourselves in the lab, they would remember and understand more. This is especially needed for students with disabilities. In their case, without active methods, there are no results" (W-4/2/S).

"I would not say it is a waste of time [about remote education], but there is no doubt, plenty will have to be repeated. Returning to school will be difficult not only due to a lack of knowledge but also to social problems. Children need their peers for proper development. I have information from many parents that they notice depressive behaviours. It affects all children, disabled as well" (W-22/2/H).

Teachers also notice chances as a result of remote education. They point, for example, to new possibilities in supporting the education of children with disabilities.

"Remote education forced me to use many new solutions, I will use them in the future" (W-11/3/H).

"This could be an excellent solution for work with ill students" (M-1/1/S).

"I do not know why no one has come up with it so far, to partially work remotely in case of individual teaching of children with disabilities" (W-10/2/S).

"I will not stop from sharing additional materials for the class with the students" (M-6/3/H).

"Work with IES (individualized educational support) or students with SEN makes more sense now, it will be easier to fix a time online that will suit everyone" (W-14/1/H).

\section{DISCUSSION}

Remote education during the pandemic highlighted problems and fears connected with inclusive education of students with disabilities. It is confirmed by the conclusion of the researchers studying the issue formulated in the context of joint education and the possibilities of fulfilling the educational program by students with light disabilities, as well as mild and major ones, especially when it is expected they meet the requirements (Meynert, 2014, p. 9).

Closing the school, as the effect of the pandemic, is a problem especially for children with disabilities. Among children with disabilities (special health needs: mental, behavioural), for about $80 \%$, closing schools means losing access to key services (Masonbrink \& Hurley, 2020).
It is necessary to realise that there is a connection between disability and the economic situation of families with a child with a disability. As it turns out, it influences the possibility to participate in education supported by new technologies by students with disabilities.

This is vital especially in the context of future education after the pandemic ceases. According to the conducted research, it is unequivocally clear that the teachers noticed possibilities given by the usage of new technologies and they intend to use them in their work with students, for example, in situations when the student is absent for a longer time, individual consultation, didactic support, or in contacts with parents, planning and realising meetings of specialized teams.

It confirms the findings of many authors pointing that realising that there is a connection between disability and poverty is extremely important for planning effective inclusive strategies (Palmer, 2011, Mitra et al., 2013, Van der Mark et al., 2017). It is also worth pointing out that according to the Central Statistical Office of Poland (Economic poverty rates..., 2020, p. 3) from 2019 the economic grinding poverty rate in Poland among families with children with disabilities is significantly higher than in households without a disabled person. If in the family there is at least one person with a disability, the economic grinding poverty rate reported in 2019 was at a level of $6.5 \%(7.8 \%$ in the year 2018). If in the family there is a child with a disability up to the age of 16 , the rate in 2019 was $5.5 \%$, with $3.7 \%$ in the case of families without a child with a disability.

Teachers participating in the research see among students with disabilities or special educational needs bigger problems with adjusting to the remote education, but also to conditions of isolation, including peer isolation, that can have detrimental consequences in terms of developing their social and behavioral competencies. The isolation experienced during the pandemic is something opposite to what people with disabilities need for social development (UNESCO, 2020).

Parallel is the results of Joyce Lee's observation (Lee, 2020) pointing out the lack of peer interactions can in a group of people with special educational needs (ASD, ADHD, MPD, difficulties in learning, slower development, and other behavioural and emotional difficulties), result in skills regression. According to Lee's research, among students with SEN remote education intensified 
difficulties in fulfilling instructions and independent task completion. Among students with ADHD, it was noticed, as a result of remote education, an increase in confrontationality in relations with parents or more common anger outbursts (Cortese, et al., 2020).

\section{CONCLUSIONS AND RECOMMENDATIONS}

Teachers participating in the research all agree that remote education of students with disabilities is a bigger challenge than of students without any developmental disorders. The results of the research shows three main areas around which the responses of the research group are concentrated in terms of remote inclusive education of students with disabilities. The first is the participation of students with disabilities in remote classes. Teachers point to lower rates of participation of this group of students in remote classes. There are several reasons for this teacher-diagnosed situation. Among them are no equipment (not enough equipment in the context of family needs, old, broken down equipment); lack of students' IT competencies, lower than in the general population's IT competencies of the parents who cannot support their children at the necessary technical level.

Another reason is a worse adaptation to remote learning conditions of children with disabilities connected with their possibilities and needs. The research points to attention and concentration disorder, not understanding the instructions, not following the flow of the lesson, lack of the possibility to individualize the work and adjust it to the needs of the students. The second problem arising from the research is the fear of the teachers regarding the regression in school competencies of the students. It is mainly connected to social competencies. Lack of relations with peers can result in the decline of such arduously gained skills of functioning in a group. It corresponds to teachers' awareness that during the pandemic, in case of many students with disabilities, possibilities to participate in onsite therapy are fewer, or in some cases even ceased.

Teachers see the results of this in current relations with students. There is a visible regress of such skills like independence, responsibility, ability to cooperate. Teachers also noticed the phenomenon of "disappearing" students, not participating in school classes. It is, on one hand, the result of intensified difficulties and on the other a lack of continuity in therapy and fewer possibilities of adjusting to the conditions of remote education. Non-participa- tion of students in classes is a greater problem in terms of students with disabilities rather than with developmental disorders. Most commonly, this phenomenon is observed in bigger cities rather than smaller towns or villages. It is connected most likely with a larger engagement of the parents from bigger cities in their remote work, which in the case of a lack of or problems with equipment can be one of the explanations of the student's absence in classes and lower parental control in terms of the children's education.

The third problem arising from the research connected with remote education of students with disabilities is the post-pandemic perspective of inclusive education of this group of students. Teachers notice positive aspects of remote education, for example, ease of contact with the student, parent, and specialists. They intend to use gained experience in future onsite education. The problem they notice here, however, is the previously mentioned low IT competencies of students with disabilities and their parents, and a lack of equipment. Among the fears, there is one common opinion that the biggest challenge of post-pandemic education will be coping with the psychological problems of the students. Teachers are sure that the problem will not only be a regression of social competencies of students with disabilities but also new problems such as anxiety resulting from feeling safe both physically, as well as mentally in social relations.

The experience of remote education on the level of primary school significantly points to a worse educational situation of students with disabilities which has notable meaning in the context of inclusive education. It emphasizes with even greater power that inclusive education in terms of this group of students will require the activation of more effective mechanisms of support that go beyond purely didactic aspects. It needs to be foreseen that the support will have to be concentrated more in so far as the social and mental functioning areas of the students are concerned. It will require greater accessibility to fast paths of diagnosis and therapy so serious disorders in psycho-social functioning do not appear. Teachers should also prepare themselves for careful diagnosis of the psycho-social functioning of students with disabilities. However, the problem is that the majority of them do not have competencies in this area. Thus, it seems necessary to plan systematic actions in the forms of workshops and meetings with specialists introducing these topics, and giving basic orientation in the problem. 
What is positive regarding the effect of remote education is the increased awareness of the meaning and value of the cooperation of teachers and parents of students with disabilities. The parents had an opportunity to see up close the work of the teachers; their effort was put into working with their children. The teachers, on the other hand, saw in the parents of their students with disabilities, specialists from whom they can learn a lot and with whom cooperation can translate into an easier coping with possible difficulties when working with students with disabilities from the perspective of returning to school after an over-a-year gap of remote education.

\section{ACKNOWLEDGEMENT}

None.

\section{DISCLOSURE STATEMENT}

No potential conflict of interest was reported by the authors.

\section{FUNDING}

None.

\section{REFERENCES}

Avramidis, E., Bayliss, P., \& Burden, R. (2000). A Survey into Mainstream Teachers' Attitudes Towards the Inclusion of Children with Special Educational Needs in the Ordinary School in one Local Education Authority. Educational Psychology, 20(2), 191211. https://doi.org/10.1080/713663717

Avramidis, E., \& Norwich, B. (2002). Teachers' Attitudes Towards Integration/Inclusion: A Review of the Literature. European Journal of Special Needs Education, 17(2), 129-147. https://doi.org/10.1080/08856250210129056

Child disability and COVID-19 (2020). UNICEF https://data.unicef.org

Cortese, S., Asherson, P., Sonuga-Barke, E., Banaschewski, T., Brandeis, D., Buitelaar, J., Coghill, D., Daley, D., Danckaerts, M., Dittmann, R. W., Doepfner, M., Ferrin, M., Hollis, C., Holtmann, M., Konofal, E., Lecendreux, M., Santosh, P., Rothenberger, A., Soutullo, C. \& Simonoff, E. (2020). ADHD Management During the COVID-19 Pandemic: Guidance from the European ADHD Guidelines Group. Lancet Child Adolesc. Health. https://doi.org/10.1016/S2352-4642(20)30110-3

Douglas, M., Katikireddi, S. V., Taulbut, M., McKee, M., \& McCartney, G. (2020). Mitigating the Wider Health Effects of COVID-19 Pandemic Response. BMJ, 369, m1557. https://doi.org/10.1136/bmi.m1557

Economic poverty rates in Poland in 2019. (2020). Statistics Poland. https://stat.gov.pl/en/topics/living-conditions/social-assistance/economic-poverty-rates-in-poland-in-2019,4,7.html

Evans, J., \& Lunt, I. (2002). Inclusive Education: Are there Limits? European Journal of Special Need Education, 17(1), 1-14. https://doi.org/10.1080/08856250110098980

Forlin, C. (2001). Inclusion: Identifying potential stressors for regular class teachers. Educational Research, 43(3), 235-245. https:// doi.org/10.1080/00131880110081017

Gallagher, T. L., \& Bennett, S. (2015). A Canadian Perspective on the Inclusion of Students with Intellectual Disabilities in High Schools. In: R.G. Craven et al. (eds.), Inclusive Education for Students With Intellectual Disabilities. IAP - Information Age Publishing.

Guba, E. G., \& Lincoln, Y. S. (1982). Epistemological and Methodological Bases of Naturalistic Inquiry. ECTJ, 30, 233-252. https://doi.org/10.1007/BF02765185

Hansen, J. H. (2012). Limits to Inclusion. International Journal of Inclusive Education, 16(1), 89-98. https://doi. org/10.1080/13603111003671632

Holmes, E., O’Connor, R., Perry, H. V., Tracey, I., Wessely, S., Arseneault, L., Ballard, C., Christensen, H., Silver, R., C., Everall, I., Ford, T., John, A., Kabir, T., Kung, K., Madan, I., Michie, S., Przybylski, A. K., Shafran, R., Sweeney, A., Worthman, C. M., Yardley, L., Cowan, K., Cope, C., Hotopf, M., \& Bullmore, E. (2020). Multidisciplinary Research Priorities for the COVID-19 Pandemic: A Call for Action for Mental Health Science. Lancet Psychiatry. https://doi.org/10.1016/S2215-0366(20)30168-1

Janoś-Kresło, M., \& Słaby, T. (2016). Rodziny opiekujące się dziećmi z niepełnosprawnością na rynku usług. Handel Wewnętrzny, 2(361), 192-204.

Johnson, S. M., Kraft, M. A., \& Papay, J. P. (2012). How Context Matters in High-Need Schools: The Effects of Teachers' Working Conditions on Their Professional Satisfaction and Their Students' Achievement. Teachers College Record, 114(10), 1-39. 
Kraft, L. A., \& Simon, N. S. (2020). Teachers' Experiences Working from Home During the COVID-19 Pandemic. https://education.brown.edu/sites/g/files/dpreri366/files/2020-06/Upbeat\%20Memo\%20-\%20Kraft.pdf

Kuhlthau, K., Hill, K., Yucel, R., \& Perrin, J. (2005). Financial Burden for Families of Children with Special Health Care Needs. Maternal and Child Health Journal, 9(2), 207-218. https://doi.org/10.1007/s10995-005-4870-x

Kuhlthau, K. A., \& Perrin, J. M. (2001). Child Health Status and Parental Employment. Archives of Pediatric and Adolescent Medicine. 155(12), 1346-1350. https://doi.org/10.1001/archpedi.155.12.1346

Lee, J. (2020). Mental Health Effects of School Closures During COVID-19. The Lancet Child \& Adolescent Health, 4(6), 421. https://doi.org/10.1016/s2352-4642(20)30109-7

Masonbrink, A. R., \& Hurley, E. (2020). Advocating for Children During the COVID-19 School Closures, Pediatrics, 146(3), e20201440. https://doi.org/10.1542/peds.2020-1440

Meynert, M. J. (2014). Inclusive Education and Perception of Learning Facilitators of Children with Special Needs in a School in Sweden. International Journal of Special Education, 29(2) 1-18.

Mitchell, D. (2005). Introduction: Sixteen Propositions on the Contexts of Inclusive Education. In: D. Mitchell (ed.). Contextualizing Inclusive Education. Evaluating Old and New International Perspectives. Routledge, 1-22.

Mitchell, L. C., \& Hedge, A. V. (2007). Beliefs and Practices of In-Service Preschool Teachers in Inclusive Settings: Implications for Personnel Preparation. Journal of Early Childhood Teacher Education, 28(4), 353-366. https://doi. org/10.1080/10901020701686617

Mitra, S., Posarac, A., \& Vick, B. (2013). Disability and Poverty in Developing Countries: A Multidimensional Study. World Development 41, 1-18. https://doi.org/10.1016/i.worlddev.2012.05.024

Palmer, M. (2011). Disability and Poverty: A Conceptual Review. Journal of Disability Policy Studies, 21(4), 210-218. https://doi. org/10.1177/1044207310389333

Parish, S. L., \& Cloud, J. M. (2006). Financial Well-Being of Young Children with Disabilities and Their Families. Social Work, 51 (3), 223-232. https://psycnet.apa.org/doi/10.1093/sw/51.3.223

Pinilla-Roncancio, M. (2015). Disability and Poverty: Two Related Conditions. A Review of the Literature. Revista de la Facultad de Medicina. 63, 113-23. http://dx.doi.org/10.15446/revfacmed.v63n3sup.50132

Purdam, K., Afkhami, R., Olsen, W., \& Thornton, P. (2008). Disability in the UK: Measuring Equality. Disability \& Society, 23(1), 53-65. http://doi.org/djrxd2

Sakellariou, D., Serrata, A., Malfitano, P., \& Rotarou, E. S. (2020). Disability Inclusiveness of Government Responses to COVID-19 in South America: A Framework Analysis Study. International Journal for Equity in Health, 19, 2-10. https://doi.org/10.1186/ s12939-020-01244-X

Savolainen, H., Engelbrecht, P., Nel, M., \& Malinen, O-P. (2012). Understanding Teachers' Attitudes and Self-Efficacy in Inclusive Education: Implications for Pre-Service and In-Service Teacher Education. European Journal of Special Needs Education, 27(1), 51-68. https://doi.org/10.1080/08856257.2011.613603

Scruggs, T. L., \& Mastropieri, M. A. (1996). Teacher Perceptions of Mainstream/Inclusion, 1958-1995. Exceptional Children, 63(1), 59-74. https://doi.org/10.1177/001440299606300106

Skivington, M. (2011). Disability and Adulthood in, Mexico: An Ethnographic Case Study. International Journal of Special Education, 26(3), 45-57. https://files.eric.ed.gov/fulltext/EJ959000.pdf

Soodak, L. C., Podell, D., M., \& Lehman, L. R. (1998). Teacher, Student, and School Attributes as Predictors of Teachers' Responses to Inclusion. The Journal of Special Education, Vol. 31(4), 480-497. https://doi.org/10.1177\%2F002246699803100405

Thomas, G., \& Loxley, A. (2007). Deconstructing Special Education and Constructing Inclusion. Open University Press.

UNESCO (2020). Including learners with disability in COVID-19 education responses. https://en.unesco.org/news/including-learners-disabilities-covid-19-education-responses

UNICEF. (2020). COVID-19 Response: Considerations for Children and Adults with Disabilities. https://sites.unicef.org/disabilities/ files/COVID-19 response considerations for people with disabilities 190320.pdf

Van der Mark, E. J., Conradie, I., Dedding, C. W. M., \& Broerse, J. E. W. (2017). How Poverty Shapes Caring for a Disabled Child: A Narrative Literature Review. Journal of International Development, 29, 1187-1206. https://doi.org/10.1002/jid.3308

Walton, E. (2015). Dismantling the Empire of Educational Exclusion. In: E. Walton \& S. Moonsamy (eds.). Making Education Inclusive, Scholars Publishing. 10-27. https://www.academia.edu/14877095/Dismantling the empire of educational exclusion

Westwood, P. (2013). Inclusive and Adaptive Teaching: Meeting the Challenge of Diversity in the Classroom, Routledge. 